\author{
DOBROSŁAWA ANTONÓW \\ ORCID: 0000-0001-8545-1932 \\ Uniwersytet Wrocławski
}

\title{
Daniny publiczne związane z użytkowaniem dróg publicznych i ruchem drogowym w ustroju demokratycznym odrodzonej Polski
}

\section{Wprowadzenie}

Odzyskanie niepodległości przez Polskę rozpoczyna nowy, niezwykle ważny okres w dziejach jej państwowości. Czas ten przyniósł wiele wyzwań wynikających z dotychczasowej imperialistycznej polityki państw zaborczych, zakładającej eliminację odrębności ustrojowych i prawnych ziem polskich oraz ich destrukcję gospodarczą, społeczną i kulturalną. Był to przede wszystkim czas kształtowania się nowego demokratycznego ustroju państwowego. Odzyskanie przez Polskę niepodległości przyniosło jednak istotne przekształcenia nie tylko polityczne i ustrojowe, lecz również społeczne i gospodarcze, gdyż odrodzona demokratyczna Polska pod względem społecznym odbudowała się jako państwo kapitalistyczne ${ }^{1}$. Transformacja ta odbywała się w realiach współistnienia regionów zróżnicowanych pod względem zarówno politycznym i prawnym, jak i społecznym i gospodarczym. Tak na przykład jako jedno z kryteriów dotyczących dysproporcji w rozwoju gospodarczym ziem polskich wskazywano sieć dróg: podczas gdy w województwach zachodnich w chwili odzyskania niepodległości przypadało $25,1 \mathrm{~km}$ dróg o twardej nawierzchni na $100 \mathrm{~km}^{2}$, to w województwach wschodnich wskaźnik ten wynosił jedynie $2 \mathrm{~km}$ na $100 \mathrm{~km}^{2}$ nawierzchni ${ }^{2}$.

Tworzenie demokratycznego ustroju odrodzonej Polski w kapitalistycznych realiach rynkowych wiązało się z intensywną działalnością legislacyjną. Badania historyczne podejmowane w obszarze nauk dogmatycznych (w tym również w obszarze prawa finansowego) dowodzą genezy wielu obecnie obowiązujących

${ }^{1}$ A. Czubiński, Znaczenie odbudowy niepodległego państwa dla narodu polskiego, ,Roczniki Historyczne" 36, 1970, s. 67.

2 Ibidem, s. 69-70. 
instytucji i rozwiązań prawnych właśnie w prawodawstwie okresu kształtowania się ustroju demokratycznego niepodległej Polski ${ }^{3}$. Zauważa się również wyraźną i oczywistą jednocześnie tendencję, że przyjęte wówczas rozwiązania prawne nawiązywały głównie do systemów prawnych państw zaborczych — porządkowały je, ujednolicały, wzorowały się na nich lub je zastępowały z zachowaniem pewnych podobieństw ${ }^{4}$. Niezależnie jednak od tego zasadne wydaje się spojrzenie na prawodawstwo analizowanego okresu również z nieco innej perspektywy. Przed odradzającym się państwem polskim stawały bowiem nie tylko wyzwania wynikające z potrzeby rekonstrukcji i porządkowania państwa i prawa po długotrwałym okresie niebytu. Równie ważne były także bieżące wyzwania, które przed całym światem (nie tylko przed odrodzoną Polską) stawiał rozwój cywilizacyjny. Polska, podobnie jak inne kraje, musiała mierzyć się na bieżąco z nowymi zjawiskami społecznymi i rozwojem techniki kształtującym realia gospodarcze tego okresu. Jednym z takich wyzwań był rozwój ruchu drogowego z udziałem pojazdów mechanicznych, wynikający z popularyzacji samochodu jako powszechnego środka transportu.

Choć w historii motoryzacji wynalezienie samochodu wiąże się z uzyskaniem patentu przez Karla Friedricha Benza w 1885 roku $^{5}$, to realnie jako początek rozwoju idei samochodu wskazuje się rok 1900, a więc początek XX wieku' ${ }^{6}$. Prawdziwy rozwój motoryzacji zaś to lata dwudzieste XX wieku. W okresie tym popularyzacji samochodu jako środka transportu towarzyszyły na świecie pierwsze działania legislacyjne związane z powszechnym wykorzystywaniem samochodu i innych pojazdów mechanicznych jako środków transportu na drogach publicznych. Wzmożona (i inna rodzajowo, bo wynikająca z ruchu pojazdów mechanicznych, a nie transportu z wykorzystaniem zwierząt pociągowych) eksploatacja dróg publicznych generowała również nowe wydatki publiczne związane z budową i utrzymaniem dróg publicznych. Wpływ rozwoju motoryzacji na aktywność państwa o ustroju demokratycznym należy zatem postrzegać z co najmniej dwóch perspektyw — po pierwsze z perspektywy szeroko pojętej legalizacji (a więc tworzenia prawa) zasad eksploatacji dróg publicznych i ruchu drogowego, po drugie zaś z perspektywy polityki wydatkowej państwa, która

3 Tak na przykład na temat znaczenia regulacji prawnych okresu rządów sanacji dla współczesnej koncepcji opłaty skarbowej pisała D. Antonów w artykule Unifikacja opłat stemplowych w okresie rządów sanacji - ustawa z dnia 1 lipca 1926 roku o opłatach stemplowych, „Studia nad Autorytaryzmem i Totalitaryzmem" 40, nr 4, s. 131-144.

4 Takie tendencje są wyraźnie dostrzegane na przykład na gruncie instytucji z zakresu prawa daninowego. Na ten temat na przykład D. Antonów, op. cit., s. 133 n.; D. Antonów, Opłata skarbowa w polskim porzadku prawnym, Warszawa 2017, s. 72-79; I. Czaja-Hliniak, Opłaty i dopłaty w Polsce międzywojennej, Kraków 2013, s. 91 n.; L. Adam, Podatki i opłaty w kapitalizmie, Warszawa 1962, s. $136 \mathrm{n}$.

5 R.M. Dell, P.T. Moseley, D.A.J. Rand, Towards Sustainable Road Transport, Oxford 2014, s. 40; J.L. Collier, The Automobile, New York 2006, s. 14.

6 J.L. Collier, op. cit., s. 25. 
powinna była uwzględniać wydatki na cele związane z budową i utrzymaniem dróg publicznych eksploatowanych przez nowe jakościowo kategorie uczestników ruchu drogowego. W literaturze analizowanego okresu zwracano uwagę, że

w ostatnich czasach przed wojną i w czasie wojny z powodu zjawienia się nowego potężnego czynnika ruchu - lokomocji samochodowej i zastosowania siły mechanicznej do przewozu ciężarów na drogach — znaczenie dróg kołowych znacznie się powiększyło, a charakter znacznie zmienił się. Komunikacja samochodowa przestała być przedmiotem zbytku lub sportu, stała się przedmiotem codziennego użytku dając możność szybkiego przenoszenia się $\mathrm{z}$ miejsca na miejsce oraz przewożenia masowego ciężarów ${ }^{7}$.

\section{Jednocześnie zauważano:}

zarówno ruch osobowy samochodowy, jak i przewóz ciężarów przy pomocy siły mechanicznej, wywołują nadmierne zużycie nawierzchni w ogóle, a nawierzchni dróg bitych w szczególności. Przed technikami z tego powodu powstaje bardzo poważne zagadnienie: przystosowania dróg do tego nowego czynnika ruchu na drogach. $\mathrm{Z}$ drugiej strony te nowe czynniki ruchu wysuwają sprawę budowy i utrzymania dróg, jako jedno z najważniejszych zadań gospodarki społecznej ${ }^{8}$.

Biorąc pod uwagę znaczenie polityczne, gospodarcze i społeczne sieci dróg oraz zadania państwa z tym związane, w literaturze podkreślano, że w

każdym państwie ustawodawstwo i administracja drogowa tworzyły się przez całe wieki i przystosowywały się zarówno do charakteru narodu, jak i jego ustroju administracyjnego. $\mathrm{Z}$ tego powodu ustawodawstwa i ustroje administracji drogowej ogromnie różnią się w różnych krajach?.

Zadania publiczne związane $\mathrm{z}$ drogownictwem (w tym prawodawstwo drogowe, administracja drogowa i zasady finansowania budowy i utrzymania dróg) pozostają zatem w bezpośrednim związku (wynikają) z ustrojem danego państwa i jego polityką. Wpływ na te kwestie wywierają jednak także uwarunkowania historyczne, geopolityczne, społeczne i gospodarcze. W przypadku odradzającej się Polski założenie to nabierało szczególnego znaczenia. Ówcześni badacze tego problemu podkreślali bowiem wyjątkowe znaczenie drogownictwa dla Polski w tym szczególnym momencie jej historii. Zauważano, że

w Polsce gospodarka drogowa ma stosunkowo większe znaczenie, niż w jakimkolwiek kraju Zachodniej Europy, a to skutkiem po pierwsze niejednolitości jej, która powstała skutkiem rozdarcia Polski w ciągu dłuższego przeciągu czasu przez trzy państwa zaborcze, z których każde miało swój system i swoją politykę administracyjną odrębną, po drugie skutkiem zaniedbania w niektórych dzielnicach przez rządy zaborcze tej ważnej dziedziny gospodarki społecznej [...] zaniedbania w tej dziedzinie są tak znaczne, że wymagać będą może kilku-

\footnotetext{
7 M.W. Nestorowicz, Sprawa drogowa w Polsce, Warszawa 1923, s. 3-4.

8 Ibidem, s. 4.

9 Ibidem, s. 7.
} 
dziesięciu lat, aby je wyrównać i doprowadzić gospodarkę drogową do jednakowego stanu na całym terenie Rzeczypospolitej ${ }^{10}$.

Ze względu na sytuację polityczną, gospodarczą i społeczną ziem polskich przed rokiem 1918 dopiero moment kształtowania się nowej demokratycznej państwowości mógł faktycznie dać początek kształtowania polityki państwa (w tym polityki finansowej) w sprawach drogownictwa oraz ustalenia miejsca administracji drogowej w ustroju administracyjnym państwa. O ile bowiem rozkwit motoryzacji na świecie sięga początków XX wieku, o tyle w przypadku ziem polskich można o nim mówić realnie dopiero właśnie po roku 1918. W chwili odzyskania niepodległości przemysł motoryzacyjny na terenie ziem polskich nie istniał ${ }^{11}$. Państwa zaborcze nie rozwijały na ziemiach polskich ważnych dla państwa gałęzi przemysłu. Również znikomy był potencjał polskiej motoryzacji. Brakuje dokładnych danych na temat liczby samochodów znajdujących się wówczas w Polsce, niemniej jednak wskazuje się (w odniesieniu do pojazdów mechanicznych ogółem) liczbę pomiędzy 8000 a 10000 sztuk $^{12}$. Polska po roku 1918 jawi się zatem jako kraj pozbawiony własnej myśli technicznej i jakiegokolwiek przemysłu motoryzacyjnego, ale również jako kraj nielicznych zmotoryzowanych uczestników ruchu drogowego. Pomimo tego ustawodawca w odrodzonej, zdewastowanej gospodarczo Polsce podejmował próbę nadążania za rewolucją techniczną przetaczającą się przez kraje całej Europy. Przyjął on bowiem pierwsze rozwiązania systemowe związane z organizacją i finansowaniem budowy i utrzymania dróg publicznych oraz organizacją ruchu drogowego. Co istotne, przyjęte koncepcje uwzględniały zarówno potrzebę legalizacji zasad korzystania z dróg publicznych i uczestnictwa w ruchu drogowym, jak i konieczność partycypacji jego uczestników w wydatkach publicznych na drogi publiczne. Twórcy reform w zakresie drogownictwa w Polsce w latach dwudziestych XX wieku podkreślali, że

aby gospodarka drogowa w Polsce uległa radykalnej poprawie, potrzeba jest po pierwsze, aby miała pewne ramy prawne w postaci ustawodawstwa drogowego, które by sprzyjało rozwojowi dobrej gospodarki drogowej, po drugie, aby miała dobry i sprawny aparat administracyjny; po trzecie, aby miała odpowiednie środki ${ }^{13}$.

Wypadkową tych założeń okazała się między innymi koncepcja różnego rodzaju danin publicznych związanych z użytkowaniem dróg publicznych i ruchem

10 Ibidem, s. 4-5.

11 T. Wójcik, Centralne Warsztaty Samochodowe w Warszawie w latach 1918-1928: przyczynek do genezy polskiej motoryzacji, „Przegląd Historyczno-Wojskowy” 2013, nr 14 (65)/2 (244), s. 187.

12 Jak podaje T. Wójcik na podstawie dokumentów opracowanych przez Sekcję Wojsk Samochodowych Departamentu II Ministerstwa Spraw Wojskowych, w listopadzie 1920 roku w Polsce znajdowało się przeszło 10000 pojazdów mechanicznych. Na podstawie badań Głównego Urzędu Statystycznego autor ów podaje zaś, że w lipcu 1924 roku w Polsce było 8481 pojazdów mechanicznych, w tym 934 motocykli. T. Wójcik, op. cit., s. 187-188.

13 M.W. Nestorowicz, op. cit., s. 5-6. 
drogowym. Te nowe - jak na ówczesne czasy — działania legislacyjne wykreowały rozwiązania systemowe i instytucje, które, ewaluując, zachowały się do dziś.

Celem niniejszego artykułu jest wskazanie i uporządkowanie głównych kategorii danin publicznych wprowadzonych w Polsce w pierwszych latach po odzyskaniu niepodległości, związanych z użytkowaniem dróg publicznych i z ruchem drogowym. Artykuł ma charakter porządkujący i koncentruje się na wskazaniu ogólnych, pierwotnych koncepcji i tendencji w zakresie partycypacji uczestników ruchu drogowego w wydatkach publicznych poprzez różnego rodzaju daniny. Poza zakresem analizy pozostają szczegółowe badania nad konstrukcją i charakterem prawnym poszczególnych z tych danin. Niniejszy artykuł stanowić może jednak przyczynek do badań szczegółowych tego typu.

O utylitarnym charakterze zaprezentowanych w artykule badań świadczy co najmniej kilka najważniejszych argumentów. Po pierwsze, badania historyczne w ogólności stanowią istotny wkład w rozwój nauk dogmatycznych. Pozwalają bowiem dotrzeć do genezy i uzasadnienia wielu instytucji aktualnego porządku prawnego. Niejednokrotnie bowiem ustalenie ich charakteru prawnego wymaga rekonstrukcji kontekstu historycznego (zarówno politycznego, jak i gospodarczego), w którym osadzone były ich pierwotne formy. Ma to w pełni odniesienie również do prawa finansowego, w tym prawa daninowego. Po drugie, regulacje prawne analizowane w niniejszym artykule były wyrazem legalizacji wówczas zupełnie nowych zjawisk gospodarczych. Te nowatorskie rozwiązania normatywne ewoluowały i znajdują swoją kontynuację współcześnie. Po trzecie, tematyka dotycząca aspektów finansowych (zarówno z punktu widzenia wydatków publicznych na te cele, jak i świadczeń pieniężnych z tym związanych, ponoszonych przez obywateli na rzecz państwa, w tym głównie opłat) korzystania z dróg publicznych, ruchu drogowego, warunków wykonywania transportu w zakresie działalności gospodarczej itp. stanowi nadal istotny obszar badań prawników, ekonomistów oraz specjalistów w dziedzinie transportu i logistyki ${ }^{14}$. Po czwarte, publicznoprawne świadczenia pieniężne (podatki, opłaty, dopłaty) związane $\mathrm{z}$ korzystaniem z dróg publicznych, których pierwotne koncepcje zostały ukształtowane $\mathrm{w}$ analizowanym okresie początku XX wieku, stanowią współcześnie (w ich aktualnie obowiązujących formach) bardzo istotny koszt ekonomiczny przedsiębiorstw branży transportowej ${ }^{15}$.

14 Badania na ten temat zostały opisane na przykład w D. Antonów, Opłaty publiczne w dziatalności gospodarczej na przykładzie branży transportu drogowego, „Annales Universitatis Mariae Curie-Skłodowska. Sectio H. Oeconomia" 50, 2016, nr 1, s. 537-546; eadem, Opłaty publiczne na gruncie ustawy o publicznym transporcie zbiorowym - wybrane problemy, [w:] Finanse samorządowe po 25 latach samorzadności. Diagnoza i perspektywy, red. W. Miemiec, Warszawa 2015, s. 372-382; eadem, Szczególne opłaty administracyjne, Wrocław 2017, s. 201, passim (liczne opłaty omawiane w odrębnych rozdziałach, na przykład Opłaty pobierane za czynności Dyrektora Transportowego Dozoru Technicznego - s. 142).

15 Zwraca na to uwagę na przykład P. Romanow, Koszt transportu w działalności przedsiębiorstw transportu drogowego, „Logistyka” 2013, nr 2, s. 19-22; A. Szymonik, W. Gałuszczak, 


\section{Daniny publiczne związane z użytkowaniem dróg publicznych i z ruchem drogowym w ustroju demokratycznym odrodzonej Polski - zakres pojęcia}

$\mathrm{Z}$ racji porządkującego charakteru niniejszego artykułu istotne znaczenie ma przyjęcie jednoznacznych założeń badawczych, w tym zdefiniowanie zakresu znaczeniowego omawianej instytucji, a więc danin publicznych związanych $\mathrm{z}$ użytkowaniem dróg publicznych i z ruchem drogowym.

Po pierwsze, badania koncentrują się na działaniach legislacyjnych podejmowanych w realiach ustroju demokratycznego w pierwszych latach po odzyskaniu przez Polskę niepodległości, a więc po roku 1918. Są to pierwsze polskie regulacje prawne z zakresu analizowanej problematyki.

Po drugie, podejmowana problematyka merytorycznie związana jest zgodnie z tytułem artykułu — z użytkowaniem dróg publicznych i z ruchem drogowym. Określenie to stanowi skrót myślowy wobec grupy pierwszych polskich regulacji prawnych związanych z całokształtem problematyki dróg publicznych (w tym ich budowy, utrzymania i korzystania z nich), organizacji i zasad poruszania się pojazdów mechanicznych po drogach publicznych, a także kwestii związanych z ewidencjonowaniem i rejestrowaniem pojazdów oraz koncesjonowania branży transportowej. Tak rozumianego tytułowego użytkowania dróg publicznych i ruchu drogowego nie należy zatem zawężać i utożsamiać jedynie ze współczesnym rozumieniem przyjętym w ustawie z dnia 20 czerwca 1997 roku - Prawo o ruchu drogowym ${ }^{16}$. Wyodrębniony według wskazanych kryteriów merytorycznych pakiet regulacji opisowo można określić jako pakiet pionierskich polskich regulacji prawnych w przedmiocie dróg publicznych i ich użytkowania przez pojazdy mechaniczne. W tytule i ogólnej koncepcji artykułu położno akcent na kwestię ruchu drogowego z racji przyjętej we wprowadzeniu tezy, że to właśnie rozwój motoryzacji i udział pojazdów mechanicznych w ruchu drogowym stanowił asumpt do legalizacji wszelkich kwestii związanych z drogami publicznymi i ich eksploatacją.

Po trzecie, badania nad wyodrębnionymi merytorycznie (zgodnie z drugim założeniem badawczym) aktami prawnymi koncentrują się na uregulowanych tam daninach publicznych. Oznacza to, że w artykule mowa wyłącznie o publicznoprawnych,

Koszty transportu $i$ ceny ushug transportu samochodowego, „Logistyka” 2013, nr 2, s. 6-11; M. Ptak, Regionalne i lokalne opłaty $i$ podatki transportowe jako instrumenty przeciwdziatania zmianom klimatu, „Studia Ekonomiczne. Uniwersytet Ekonomiczny w Katowicach” 2013, nr 143. Współczesne uwarunkowania rozwoju transportu w regionie, s. 333-340.

16 Dz.U. z 2018 r. poz. 1990 tekst jedn. 
przymusowych świadczeniach pieniężnych ${ }^{17}$. Poza zakresem analizy pozostają świadczenia $w$ naturze związane z utrzymaniem dróg publicznych ${ }^{18}$.

Należy ponadto zaznaczyć, że dalsze rozważania koncentrują się na regulacjach prawnych wprowadzających i określających konstrukcję danin publicznych związanych z użytkowaniem dróg publicznych i z ruchem drogowym, a nie na wszelkich regulacjach prawnych przyjmowanych przez Polskę w związku z obciążeniami publicznoprawnymi kierowców. W związku z tym poza zakresem analizy pozostają na przykład ówczesne przepisy z zakresu prawa celnego, dotyczące preferencji celnych wobec zagranicznych środków przewozowych ${ }^{19}$, czy też ważne osiągnięcie Polski na arenie międzynarodowej, jakim była ratyfikacja konwencji o sposobie opodatkowania obcokrajowych pojazdów mechanicznych, podpisana w Genewie dnia 30 marca 1931 roku $^{20}$.

\section{Regulacje prawne w przedmiocie dróg publicznych i zasad ich użytkowania}

Zasadnicze znaczenie dla podjętych badań ma ustalenie statusu dróg w Polsce po roku 1918. W tym celu należy się odnieść w pierwszej kolejności do tak zwanego ustawodawstwa drogowego ${ }^{21}$. Była to przede wszystkim ustawa $\mathrm{z}$ dnia 10 grudnia 1920 roku o budowie i utrzymaniu dróg publicznych w Rzeczypospolitej

$17 \mathrm{Na}$ temat pojęcia i cech danin publicznych D. Antonów, Cechy danin publicznych w polskim systemie prawa, „Annales Universitatis Mariae Curie-Skłodowska. Sectio G. Ius” 2016, nr 1, s. 7-22.

18 Jedynie tytułem przykładu należy wskazać kategorię świadczeń drogowych w naturze, o których mowa w art. 28-33 u.b.u.d.p. (Świadczenia drogowe w naturze). Zgodnie z art. 28 w razie zagrożenia lub przerwania komunikacji na drogach państwowych, wojewódzkich i powiatowych (spowodowanego wypadkami żywiołowymi, takimi jak: zaspy śnieżne, powodzie, usuwiska) organy administracyjne państwowe pierwszej instancji, a w wypadkach nagłych władze gminne, mogły zarządzić dostarczenie środków przewozowych i robocizny.

19 Na podstawie $\S 1$ rozporządzenia Ministra Skarbu z dnia 18 lipca 1935 roku o odprawie celnej środków przewozowych (Dz.U. R.P. z 1935 r. Nr. 60, poz. 387) zagraniczne środki przewozowe (między innymi samochody i motocykle) wprowadzane do polskiego obszaru celnego przez osoby zamieszkałe za granicą, a przybywające na czasowy pobyt do polskiego obszaru celnego, mogły być czasowo zwolnione od cła i ograniczeń przewozowych, jeśli miały służyć do osobistego użytku tych osób.

20 Dz.U. R.P. z 1934 r. Nr 98, poz. 900 (ratyfikowana zgodnie z ustawą z dnia 5 marca 1934 roku — Dz.U. R. P. z 1934 r. Nr 27, poz. 218). Na podstawie art. 1 konwencji pojazdy mechaniczne, zarejestrowane na terytorium jednej ze stron konwencji, kursujące czasowo na terytorium innej strony, zwolnione były, pod warunkami dokładnie określonymi w konwencji, od podatków i opłat, którymi obciążony był ruch pojazdów mechanicznych lub ich posiadanie na całym terytorium tej strony konwencji lub części jej terytorium.

21 Pojęciem tym posługiwano się w literaturze analizowanego okresu, na przykład M.W. Nestorowicz, op. cit., s. 95. 
Polskiej $^{22}$ (dalej: u.b.u.d.p.). Ustawie tej przypisywano szczególne znaczenie, jako że obowiązywała ona dla całej Rzeczypospolitej i ujednolicała dotychczas zróżnicowane ustawodawstwo drogowe w poszczególnych dzielnicach, a także miała charakter ramowy rozumiany w ten sposób, że mogła być łatwo przystosowana w każdej dzielnicy do potrzeb i warunków miejscowych ${ }^{23}$.

I tak, od roku 1920 wyodrębniona została kategoria normatywna dróg publicznych. Ustawodawca w u.b.u.d.p. zdefiniował i sklasyfikował drogi publiczne oraz określił zasady ich podziału, budowy, utrzymania i zasad korzystania z nich. Ustawa ta zastąpiła trzy wcześniejsze akty tymczasowe, to jest dekret z dnia 8 lutego 1919 roku w przedmiocie tymczasowych przepisów o zarządzie drogami kołowemi ${ }^{24}$ i wydane na jego podstawie rozporządzenie Ministra Robót Publicznych z dnia 9 maja 1919 roku w przedmiocie regulaminu Komitetu Drogowego przy Ministerstwie Robót Publicznych ${ }^{25}$ oraz rozporządzenie Rady Ministrów z dnia 20 maja 1920 roku w przedmiocie stosunku służbowego inżynierów drogowych $^{26}$. Ustawę tę można określić jako pierwszy polski akt prawny określający status dróg publicznych, będący genezą normatywną współczesnych regulacji prawnych $\mathrm{w}$ tej kwestii. Należy bowiem zauważyć, że ustawa ta obowiązywała przez czterdzieści dwa lata i została zastąpiona dopiero przez ustawę z dnia 29 marca 1962 roku o drogach publicznych ${ }^{27}$, którą z kolei zastąpiła obecnie obowiązująca ustawa $\mathrm{z}$ dnia 21 marca 1985 roku o drogach publicznych ${ }^{28}$.

Artykuł 1 u.b.u.d.p. klasyfikował - adekwatnie do ustroju Polski opartego na decentralizacji władzy i wyodrębnieniu samorządu terytorialnego - drogi publiczne na państwowe, wojewódzkie, powiatowe i gminne. Podział ten miał dalsze znaczenie w kontekście zasad finansowania budowy i utrzymania poszczególnych kategorii dróg uregulowanych w dalszych czterdziestu artykułach tej ustawy.

Uzupełnieniem regulacji w przedmiocie budowy i utrzymania dróg publicznych były zasady korzystania z tych dróg. Kwestię tę regulowała ustawa z dnia 7 października 1921 roku o przepisach porządkowych na drogach publicznych ${ }^{29}$ (dalej: u.p.p.d.p. ${ }^{30}$. Zgodnie z jej art. 1 używanie dróg było dozwolone przy zachowaniu przepisów tej ustawy oraz rozporządzeń wydanych na jej podstawie. Ustawa ta, podobnie jak u.b.u.d.p., ewoluowała w polskim porządku prawnym

22 Dz.U. R.P. z 1921 r. Nr. 6, poz. 32.

23 M.W. Nestorowicz, op. cit., s. 95.

24 Dz.Praw. P.Pol. z 1919 r. Nr 14, poz. 149.

25 Dz.Praw. P.Pol. z 1919 r. Nr 39, poz. 286.

26 Dz.U. z 1920 r. Nr 47, poz. 289.

27 Dz.U z 1962 r. Nr 20, poz. 90.

28 Dz.U. z 2018 r. poz. 2068 tekst jedn.

29 Dz.U. R.P. z 1921 r. Nr 89, poz. 656 ze zm.

30 Ustawa zastąpiona przez ustawę z dnia 29 marca 1962 roku o drogach publicznych, Dz.U. z 1962 r. Nr 20, poz. 90. Na temat tej ustawy szerzej M.W. Nestorowicz, op. cit., s. 108 n. 
i została zastąpiona przez przywołane już dwie ustawy o drogach publicznych: z 1962 roku i obecnie obowiązującą z 1982 roku.

Wymienione akty prawne jednoznacznie umiejscowiły wszelkie kwestie związane $\mathrm{z}$ drogami publicznymi w obszarze zadań publicznych odrodzonej Polski. Na podstawie art. 9 u.b.u.d.p. ogólna polityka drogowa, zarząd dróg i zwierzchni nadzór nad stanem istniejących i budową nowych dróg publicznych wszystkich kategorii oraz nad gospodarką drogową pod względem technicznym i administracyjnym należał do Ministerstwa Robót Publicznych ${ }^{31} \mathrm{w}$ porozumieniu z Ministerstwem Spraw Wewnętrznych. Wyodrębnienie zadania publicznego związanego z drogami publicznymi w sposób naturalny rodziło skutki dla budżetów publicznych (państwowego i samorządowych) polegające na konieczności realizacji wydatków publicznych na te cele. Mianowicie, na podstawie art. 19 u.b.u.d.p. koszty budowy i utrzymania dróg państwowych ponosił Skarb Państwa, zaś budowa i utrzymanie dróg wojewódzkich, powiatowych i gminnych dokonywana była odpowiednio z funduszy wojewódzkich, powiatowych i gminnych. Już jednak na tym pierwszym etapie kształtowania polityki (w tym polityki wydatkowej) państwa w przedmiocie dróg publicznych ustawodawca dostrzegł konieczność partycypacji użytkowników dróg publicznych w kosztach ich budowy i utrzymania. Partycypacja ta miała różne formy. Były to przede wszystkim daniny celowe nazywane głównie opłatami, lecz także podatki. Daniny te stanowiły głównie wpływy (dochody) Państwowego Funduszu Drogowego.

\section{Państwowy Fundusz Drogowy}

Na podstawie ustawy z dnia 3 lutego 1931 roku o Państwowym Funduszu Drogowym $^{32}$ (dalej: u.p.f.d.) utworzono Państwowy Fundusz Drogowy (dalej: PFD). Zgodnie $\mathrm{z}$ art. 1 u.p.f.d. PFD był osobą prawną i został utworzony w celu dostarczenia środków na budowę, utrzymanie i wzmocnienie dróg państwowych oraz udzielenia zapomóg na budowę, utrzymanie i wzmocnienie dróg samorządowych. Wpływy PFD stanowiły: opłaty od pojazdów mechanicznych oraz niektórych pojazdów konnych, wpływy z opodatkowania materiałów pędnych, wpływy z opłat od reklam umieszczonych wzdłuż dróg publicznych, poza granicami miasta, opłaty pobierane na rzecz Skarbu Państwa na podstawie u.b.u.d.p., u.p.p.d.p., ustawy z dnia 22 marca 1933 roku o zarobkowym przewozie osób pojazdami mechanicznymi w obrębie gminy miejskiej ${ }^{33}$ (dalej: u.z.p.o.p.m.), z dotacji Skarbu Państwa, z grzywien, z państwowych wytwórni materiałów drogowych oraz ze sprzedaży państwowych materiałów drogowych niepotrzebnych w celach drogowych. Ustawa ta zawierała szczegółowe regulacje dotyczące niektórych opłat

31 Przemianowane później na Ministerstwo Komunikacji.

32 Dz.U. R.P. z 1933 r. Nr 45, poz. 352.

33 Dz.U. R.P. z 1933 r. Nr 32, poz. 273. 
stanowiących wpływy PFD, częściowo zaś w zakresie pozostałych opłat odsyłała do odrębnych ustaw. Warto zauważyć dodatkowo, że w u.p.f.d. wyodrębniony został rozdział V poświęcony wymiarowi, poborowi i ściąganiu opłat uregulowanych w tej ustawie. Przepisy tego rozdziału stanowiły regulację o charakterze ogólnym i proceduralnym (między innymi zasady ściągania opłat $\mathrm{w}$ trybie administracyjnym wraz z karami — odsetkami — oraz kosztami egzekucyjnymi, sankcję za nieuiszczenie opłat we właściwym terminie w postaci utraty ważności dowodu rejestracyjnego pojazdu, zwrot opłaty itp.).

Na podstawie u.p.f.d. można zatem stwierdzić, że w odrodzonej Polsce nastąpiło wyodrębnienie zadania publicznego (budowa i utrzymanie dróg publicznych) i jednocześnie wyodrębnienie instytucjonalne państwowej osoby prawnej - Państwowego Funduszu Drogowego jako podmiotu kompetentnego w zakresie finansowania tego zadania. Przyjąć należy zatem, że ustawa dała początek administracji drogowej, ustalając jednocześnie jej miejsce w ustroju administracyjnym państwa. Ustawa ta kreowała również w pewnym sensie „system” danin publicznych i innych świadczeń publicznych stanowiących źródło finansowania zadań związanych z drogownictwem. Daniny te był pobierane na podstawie różnych aktów prawnych.

\section{Opłaty od pojazdów mechanicznych i od niektórych pojazdów konnych}

Opłaty od pojazdów mechanicznych i od niektórych pojazdów konnych pobierane były na podstawie rozdziału II u.p.f.d. Artykuł 6 ustanawiał opłatę od pojazdów mechanicznych w stosunku rocznym. Opłata była zróżnicowana ze względu na rodzaj pojazdu mechanicznego i jego masy. Pobierana była od: pojazdów mechanicznych osobowych, pojazdów mechanicznych ciężarowych i traktorów, od pojazdów mechanicznych ciężarowych i traktorów używanych do zarobkowego przewozu towarów, od motocykli bez przyczepki, od motocykli z przyczepką oraz od trzykołowych pojazdów mechanicznych (cyklonetek). Artykuł 7 u.p.f.d. ustanawiał ponadto opłaty od pojazdów mechanicznych i konnych używanych do zarobkowego przewozu osób poza obszarami jednej gminy. Opłaty te były pobierane w stosunku rocznym od pojazdów mechanicznych (od każdego miejsca w pojeździe przeznaczonego dla podróżnego za każdy kilometr dziennego przebiegu), od pojazdów mechanicznych używanych doraźnie, od pojazdów konnych. Odrębnie, na podstawie art. 8 u.p.f.d., pobierana była opłata od pojazdów konnych używanych do zarobkowego przewozu towarów poza obszarami jednej gminy. Artykuł 11 u.p.f.d. przewidywał katalog pojazdów zwolnionych od opłat, w tym między innymi pojazdów władz i urzędów państwowych, przedsiębiorstw państwowych, instytucji i zakładów użyteczności publicznej. 
Ponadto na podstawie upoważnienia zawartego w art. 10 u.p.f.d. wydane zostało rozporządzenie Rady Ministrów z dnia 12 lipca 1934 roku o zwolnieniu od opłat niektórych pojazdów mechanicznych ${ }^{34}$. I tak, na podstawie $\S 1$ tego rozporządzenia zwolnione od opłat zostały na przykład pojazdy mechaniczne specjalnie przystosowane do przewożenia osób niemogących przenosić się o własnych siłach i wyłącznie przez takie osoby używane do tego celu.

Zakres podmiotowy opłat został uregulowany w art. 12 u.p.f.d., zgodnie z którym do uiszczenia opłat od pojazdów mechanicznych zobowiązana była osoba, na którą pojazd był zarejestrowany, a od pojazdów konnych właściciel pojazdu. Obowiązek ten powstawał z chwilą dopuszczenia pojazdu do ruchu. Ciekawym rozwiązaniem przewidzianym $\mathrm{w}$ tym przepisie była zasada, zgodnie $\mathrm{z}$ którą $\mathrm{w}$ razie przerwy w komunikacji wskutek siły wyższej władza pobierająca opłatę mogła przyznać stosowne potrącenia.

Konstrukcje opłat od pojazdów mechanicznych wskazują na podobieństwa względem współczesnego podatku od środków transportowych. Danina ta jednak miała dalece szerszy zakres przedmiotowy i obejmowała w zasadzie wszystkie pojazdy mechaniczne, a nawet niektóre pojazdy konne. Jako cechę tego świadczenia niewątpliwie warto wskazać wpływ przeznaczenia pojazdu na wysokość obciążenia (zwłaszcza jego zarobkowe wykorzystywanie) oraz objęcie zwolnieniem pojazdów należących do podmiotów publicznych i osób niepełnosprawnych (funkcje pozafiskalne opłaty). Na uwagę zasługuje również powiązanie obowiąz$\mathrm{ku}$ z tytułu opłaty z dopuszczeniem pojazdu do ruchu (faktyczną jego eksploatacją na drogach publicznych). Odpowiednio zaś brak możliwości uczestnictwa w ruchu drogowym wskutek siły wyższej upoważniał do potrącenia wysokości opłaty.

\section{Dodatek drogowy do państwowego podatku od olejów mineralnych}

Rozdział III u.p.f.d. przewidywał interesujące rozwiązanie, a mianowicie opodatkowanie materiałów pędnych. Zgodnie z art. 14 u.p.f.d. ustanowiony został dodatek drogowy do państwowego podatku od olejów mineralnych. Dodatkowi podlegały oleje mineralne, które mogły być używane do napędu pojazdów mechanicznych. Dodatek był pobierany od $1 \mathrm{~kg}$ materiałów pędnych przez właściwe władze skarbowe łącznie z podatkiem od olejów mineralnych. Do dodatku zastosowanie miały odpowiednio przepisy o podatku od olejów mineralnych. Ustawa przewidywała również zwolnienia od dodatku drogowego, obejmujące między innymi oleje wywożone pod kontrolą skarbową za granicę lub używane do napędu silników statków powietrznych wojskowych i cywilnych.

34 Dz.U. R.P. z 1934 r. Nr 69, poz. 636. 
Dodatek do podatku, będący w istocie również podatkiem, obciążał materiały pędne, a więc takie, które warunkowały eksploatację pojazdów mechanicznych w ruchu drogowym. W taki więc sposób pozostawał w związku z eksploatacją dróg publicznych. Cechy omawianego dodatku (podatku) wskazują na podobieństwo do współczesnych form opodatkowania paliw silnikowych.

\section{Opłaty od reklam umieszczanych wzdłuż dróg publicznych}

W rozdziale IV u.p.f.d. została uregulowana opłata od reklam. Na podstawie art. 16 u.p.f.d. opłata ta była pobierana od reklam (znaków, szyldów, napisów) umieszczanych wzdłuż dróg publicznych na budynkach, słupach, kioskach itp. poza granicami miast. Była ona pobierana w stosunku rocznym w wysokości ustalonej do jednego metra kwadratowego powierzchni reklamy. Na podstawie art. 17 u.p.f.d. od opłat zwolnione były reklamy przedsiębiorstw przemysłowych i handlowych umieszczone na budynkach i ogrodzeniach tych budynków, w których znajdowały się dane przedsiębiorstwa przemysłowe lub handlowe.

Konstrukcja tej opłaty przypomina współczesną koncepcję opłaty reklamowej. Przedmiotem tej opłaty były reklamy eksploatujące otoczenie dróg publicznych - umieszczane wzdłuż dróg. Taki związek z drogami publicznymi uzasadniał najprawdopodobniej jej pobór z przeznaczeniem na potrzeby związane z budową i utrzymaniem dróg publicznych.

\section{Opłaty specjalne na budowę i utrzymanie dróg}

Zgodnie z art. 19 u.b.u.d.p. budowa i utrzymanie dróg wojewódzkich, powiatowych i gminnych dokonywana była odpowiednio z funduszy wojewódzkich, powiatowych i gminnych. Co jednak istotne, ustawodawca przewidział, że fundusze wojewódzkie i powiatowe były tworzone ze źródeł ogólnosamorządowych bądź też z opłat specjalnych przeznaczonych na ten cel i uchwalonych przez wojewódzkie lub powiatowe związki samorządowe ${ }^{35}$. W ten sposób wykreowana została kategoria opłat specjalnych na budowę i utrzymanie dróg. Z przepisu tego wynikało tylko kilka (niezbyt szczegółowych) cech tych świadczeń. Były to: ich nazwa (opłaty specjalne), zadeklarowany w nazwie specjalny charakter (wskazujący na przeciwieństwo charakteru ogólnego), charakter celowy (z przeznaczeniem na ustawowo zdefiniowany cel — budowa i utrzymanie dróg wojewódzkich lub powiatowych), podstawa poboru (uchwała wojewódzkich lub powiatowych związków samorządowych). Ponadto należy podkreślić związek tych opłat

35 Na temat opłat tego typu szerzej I. Czaja-Hliniak, op. cit., s. 339 n.; J. Horszowski, Daniny komunalne na utrzymanie i budowę komunalnych dróg publicznych, ,Ruch Prawniczy, Ekonomiczny i Socjologiczny" 1924, nr 2, s. 199 n. 
wyłącznie z finansowaniem dróg powiatowych lub wojewódzkich (nie dotyczyły finansowania dróg gminnych i państwowych).

Bardziej szczegółowo kwestię opłat specjalnych regulował okólnik nr 33 z dnia 11 maja 1936 roku w sprawie opłat specjalnych i dopłat drogowych (Nr SF. 66-5-2) ${ }^{36}$. Na podstawie tego dokumentu specjalne opłaty drogowe mogły być wprowadzane tylko wtedy, gdy wydatki na utrzymanie i budowę drogi nie mogły być $\mathrm{w}$ całości lub w części pokryte z nadwyżki innych dochodów związku samorządowego nad wszystkimi innymi zwyczajnymi i nadzwyczajnymi wydatkami. Zakładano, że suma specjalnych opłat drogowych nie mogła przekraczać kwoty wydatków preliminowanych w budżecie na utrzymanie i budowę dróg, zmniejszonej o sumę wpływów budżetowych, mającą specjalne przeznaczenie na wydatki drogowe. Dochody te nie mogły być przeznaczane na pokrycie innych wydatków i podlegały szczególnemu nadzorowi władz. Przyjęto, że specjalne opłaty drogowe mogły obciążać: grunty (w postaci dodatków do państwowego podatku od gruntów lub w postaci samoistnego podatku komunalnego), przedsiębiorstwa przemysłowe i handlowe, nieruchomości w miastach niewydzielonych, nieruchomości w gminach wiejskich, podlegające państwowemu podatkowi od nieruchomości oraz nowo wzniesione budowle wolne od podatku państwowego. Okólnik określał również procentowe limity wysokości opłat.

Wbrew nazwie opłaty te powiązane były nie z drogami, lecz z wybranymi nieruchomościami i stanowiły $\mathrm{w}$ istocie obciążenie publicznoprawne nieruchomości z przeznaczeniem celowym - związanym z finansowaniem dróg publicznych.

\section{Dopłaty drogowe}

Jako dopłaty drogowe rozumiano udział w kosztach budowy i utrzymania dróg ${ }^{37}$. Na podstawie art. 23 u.b.u.d.p. otrzymujący z budowy lub utrzymania dróg szczególne korzyści lub też nadmiernie zużywający drogi, jak na przykład kopalnie, fabryki i inne przedsiębiorstwa, mogli być pociągani do udziału w kosztach budowy i utrzymania dróg przez Ministerstwo Robót Publicznych na rzecz dróg państwowych, zaś przez odnośne związki samorządowe na rzecz dróg wojewódzkich, powiatowych i gminnych, o ile wcześniej nie nastąpiła dobrowolna w tym względzie ugoda. Wymienione podmioty, które mogły zostać obciążone dopłatą, stanowiły jedynie przykłady. Zasadniczo przyjmowano, że są to właściciele nieruchomości przylegających do drogi ${ }^{38}$, tak zwani adiacenci strefy przydrożnej ${ }^{39}$. Obciążone mogły być również inne podmioty, o ile stawały się one beneficjentami szczególnych korzyści wynikających z faktu budowy drogi,

36 Dz.Urz. Min.Kom. z 1937 r. Nr 52, poz. 4567.

37 I. Czaja-Hliniak, op. cit., s. 342.

38 J. Horszowski, op. cit., s. 195.

39 Ibidem. 
lub też swoją działalnością przyczyniały się do jej szczególnego obciążenia. Przewidziana w ustawie możność pociągnięcia do udziału w kosztach sugeruje fakultatywność dopłaty. Jednak należy zauważyć, że fakultatywność ta odnosi się do warunku wcześniejszego zawarcia ugody ${ }^{40}$. Również ta kategoria danin nawiązuje do współczesnych form opłat adiacenckich, które swoją zasadniczą koncepcję czerpią z rozwiązań okresu pierwszych lat po odzyskaniu niepodległości.

\section{Opłaty za używanie dróg publicznych}

W art. 9 u.p.p.d.p. przewidziana była również inna kategoria opłat — opłata za tak zwane używanie drogi. Zgodnie z tym przepisem Minister Robót Publicznych został upoważniony do ustalenia (w porozumieniu $\mathrm{z}$ określonymi podmiotami) sposobu używania pasa drogowego do przeprowadzenia kolei, tramwajów, przewodów elektrycznych, wodociągów, gazociągów, urządzeń odwadniających itp. Co ważne, właściwe przedsiębiorstwa zostały zobowiązane do wykonania na swój koszt robót potrzebnych do zabezpieczenia trwałości drogi i bezpieczeństwa ruchu oraz do utrzymania wykonanych w tym celu urządzeń. Ustawodawca przewidział, że za używanie drogi w przewidziany w tym przepisie sposób mogła być pobierana oznaczona opłata na rzecz właściwego zarządu drogowego na zasadzie porozumienia się przedsiębiorstwa z tym zarządem, o ile na skutek używania drogi na potrzeby wymienionych urządzeń wzrastały koszty utrzymania drogi. Opłata ta jednak na podstawie omawianego przepisu nie mogła przewyższać wysokości wzrostu kosztów utrzymania drogi. Ustawodawca przyjął, że w sytuacji braku porozumienia co do wysokości opłaty wysokość tę określał wojewoda (w odniesieniu do dróg gminnych i powiatowych), a w odniesieniu do pozostałych dróg - Minister Komunikacji.

Ta kategoria opłat została powiązana bezpośrednio z wyspecjalizowaną formą eksploatacji dróg w celach rozbudowy infrastruktury. Infrastruktura tego typu w ocenie prawodawcy stanowiła istotne obciążenie dla stanu dróg publicznych, co w perspektywie mogło generować wzrost wydatków publicznych na utrzymanie obciążonej w ten sposób drogi.

\section{Opłaty związane z dopuszczenie pojazdów mechanicznych do ruchu na drogach publicznych}

Zupełnie inny rodzaj świadczeń stanowiły opłaty związane z dopuszczeniem pojazdów mechanicznych do ruchu na drogach publicznych. Rozporządzenie Ministrów Komunikacji, Spraw Wewnętrznych i Spraw Wojskowych z dnia 27 paź-

40 Ibidem, s. 343. 
dziernika 1937 roku, wydane w porozumieniu z Ministrem Opieki Społecznej, o ruchu pojazdów mechanicznych na drogach publicznych ${ }^{41}$ (dalej: r.p.m.d.p.) ${ }^{42}$ regulowało wiele kwestii związanych z ruchem pojazdów po drogach publicznych. Jedną z nich była regulacja przewidziana w $\S 19$ ust. 1 lit. a) r.p.m.d.p., zgodnie z którą do ruchu na drogach publicznych dopuszczone były pojazdy mechaniczne zarejestrowane, czyli zaopatrzone w dowód rejestracyjny, zawierające również kartę kontroli opłat na rzecz PFD, albo w czasowe pozwolenie na kursowanie i w tablice rejestracyjne. Zasady składania podań o rejestrację pojazdu regulował § 21 r.p.m.d.p. Jednakże na podstawie § 24 r.p.m.d.p. właściwa władza administracyjna wydawała (na zasadach wskazanych w tym przepisie) tablicę rejestracyjną po pobraniu opłaty przewidzianej w $\S 35$ r.p.m.d.p. oraz dowód rejestracyjny wraz z kartą kontroli opłat na rzecz PFD po pobraniu należnych opłat na rzecz tego Funduszu.

Jeżeli pojazd miał być przeznaczony do jazd, które nie miały charakteru normalnego używania, zgodnie z $§ 30$ r.p.m.d.p. wojewódzka władza administracji ogólnej mogła wydawać czasowe pozwolenie na dopuszczenie pojazdu do ruchu oraz tablice ze znakami próbnymi za opłatą ustaloną przez Ministra Komunikacji. Zarządzenie Ministra Komunikacji z dnia 3 stycznia 1938 roku regulowało opłaty za korzystanie odpowiednio z od jednej do pięciu par tablic ze znakami próbnymi za każdy dzień lub miesiąc $c^{43}$.

Opłata tego typu była w istocie opłatą administracyjną (związaną z usługami administracji publicznej). Opłata ta była związana, to jest stanowiła warunek finansowy dopełnienia obowiązków administracyjnych warunkujących legalne uczestnictwo w ruchu drogowym. Stanowiła ona wpływy PFD, a więc finalnie wpływy z tego tytułu przeznaczane były na wydatki związane z budową i utrzymaniem dróg.

\section{Opłaty za tablice rejestracyjne}

Na podstawie $\S 35$ r.p.m.d.p. tablice rejestracyjne i tablice ze znakami próbnymi dostarczał władzom administracji ogólnej PFD. Opłaty za tablice rejestracyjne ustalał Minister Komunikacji. Opłaty te pobierane były na rzecz PFD

41 Dz.U. R.P. z 1937 r. Nr. 85, poz. 616.

42 Rozporządzenie zastąpione przez rozporządzenie Ministrów Komunikacji i Spraw Wewnętrznych z dnia 1 października 1962 roku w sprawie ruchu na drogach publicznych, Dz.U. z $1962 \mathrm{Nr}$ 61, poz. 295; rozporządzenie Ministrów Komunikacji i Spraw Wewnętrznych z dnia 20 lipca 1968 roku w sprawie ruchu na drogach publicznych, Dz.U. Z 1968 r. Nr 27, poz. 183 i ostatecznie ustawę z dnia 1 lutego 1983 roku Prawo o ruchu drogowym, Dz.U. z 1992 r. Nr 11, poz. 41.

43 A. Mairanc, Kodeks Automobilowy. Ustawy. Rozporządzenia. Okólniki. Orzecznictwo. Komentarz, Warszawa 1938, s. 92. 
w przypadku wydania nowych tablic i innych tablic w zamian za tablice całkowicie zniszczone lub unieważnione z powodu zagubienia.

Paragraf 38 r.p.m.d.p. przewidywał, że organ kontroli drogowej mógł zatrzymać dowód rejestracyjny między innymi z powodu nieuiszczenia opłat na rzecz PFD. Zwrot dowodu mógł nastąpić po uregulowaniu opłat. Regulacja ta była krytykowana przez kierowców. W literaturze zauważano, iż organizacje kierowców podnosiły argumenty, że przepis ten doprowadzał do unieruchomienia pojazdów w sytuacji gdy posiadacz nie mógł chwilowo uiścić należnych opłat, a tym samym tracił możliwość eksploatacji pojazdu i uzyskania środków na uiszczenie opłat ${ }^{44}$.

W odniesieniu do tej opłaty można sformułować wnioski podobne do tych dotyczących opłaty związanej z rejestracją pojazdów mechanicznych.

\section{Opłata za koncesję na zarobkowy przewóz osób lub towarów}

Zgodnie z art. 1 ust. 2 ustawy z dnia 14 marca 1932 roku o zarobkowym przewozie osób i towarów pojazdami mechanicznymi ${ }^{45}$ (dalej: u.z.p.o.t.p.m.) ${ }^{46}$ zarobkowy przewóz osób lub towarów pojazdami mechanicznymi na drogach publicznych poza obszarami jednaj gminy wymagał (z zastrzeżeniem wyjątków określonych $\mathrm{w}$ tej ustawie) uzyskania koncesji. Zgodnie $\mathrm{z}$ art. 6 u.z.p.o.t.p.m. między innymi warunki, pod którymi koncesje były udzielone, oraz wysokość opłat miały być określone w rozporządzeniu Ministerstwa Robót Publicznych wydanym w porozumieniu z zainteresowanymi ministrami.

Rozporządzeniem regulującym prezentowaną kwestię było rozporządzenie Ministra Komunikacji wydane w porozumieniu z Ministrami: Spraw Wewnętrznych, Spraw Wojskowych, Przemysłu i Handlu, Sprawiedliwości, Poczt i Telegrafów oraz Skarbu, a co do $\S 5 \mathrm{w}$ porozumieniu z Ministrem Spraw Wewnętrznych z dnia 6 lipca 1932 roku w sprawie wykonania ustawy o zarobkowym przewozie osób i towarów pojazdami mechanicznymi ${ }^{47}$ (dalej: r.w.u.z.p). Zgodnie z $§ 41$ tego rozporządzenia otrzymujący koncesję był zobowiązany do złożenia opłaty za czynności urzędowe związane z udzieleniem koncesji. Przewidziano opłatę w trzech wysokościach uzależnionych od przedmiotu koncesjonowanej działalności: przewóz

44 Ibidem, s. 102.

45 Dz.U. R.P. z 1932 r., Nr 32, poz. 336.

46 Ustawa uchylona przez ustawę z dnia 8 stycznia 1951 roku o transporcie drogowym, Dz.U. z $1951 \mathrm{r}$. Nr 4, poz. 26, następnie aktem wstępującym w to miejsce była ustawa z dnia 27 listopada 1961 roku o transporcie drogowym i spedycji krajowej, Dz.U. z 1961 r. Nr 53, poz. 297; ustawa z dnia 29 sierpnia 1997 roku o warunkach wykonywania krajowego drogowego przewozu osób, Dz.U. z 1997 r. Nr 141, poz. 942 oraz obecnie obowiązująca ustawa z dnia 6 września 2001 roku o transporcie drogowym, Dz.U. z 2019 r. poz. 58 tekst jedn.

47 Dz.U. R.P. z 1932 r. Nr 95, poz. 821. 
osób, przewóz towarów na linii, liniach lub sieci linii przewozowych, działalność na oznaczonym obszarze. Zastrzeżono również, że za czynności urzędowe w sprawie koncesji z prawem wyłączności pobierano opłatę w podwójnej wysokości. Na podstawie $\S 42$ r.w.u.z.p opłaty te uiszczane były gotówką za pośrednictwem Pocztowej Kasy Oszczędności i stanowily dochód PFD.

W okólniku z dnia 24 lipca 1933 roku w sprawie doraźnych przewozów osobowych pojazdami mechanicznymi poza obszarem jednej gminy ${ }^{48}$ zwrócono uwagę, że istnieje obawa, że właściciele osobowych pojazdów mechanicznych będą starali się obchodzić przepisy koncesyjne i pod postacią doraźnych przewozów będą uprawiali bez koncesji komunikację podlegającą zasadniczo koncesjonowaniu i w ten sposób będą uchylali się od opłat na rzecz PFD. Przyjęto zatem, że przy wykonywaniu nadzoru nad przewozami doraźnymi i innymi niekoncesjonowanymi Urzędy Wojewódzkie mogły pobierać od pojazdów używanych do doraźnych przewozów osób opłaty dzienne wnoszone z góry za te dni, w których pojazd dokonywał przewozu. Wysokość siedmiu kategorii stawek opłaty za każdy dzień kalendarzowy była zróżnicowana w zależności od liczby miejsc dla podróżujących w pojeździe. Przyjęto również, że Urząd Wojewódzki każdej osobie, której udzielono zezwolenia, wydawał „kartę kontroli opłat za doraźny przewóz”.

Opłata od koncesji stanowi również rodzaj opłaty administracyjnej (podobnie jak dwie wcześniejsze kategorie opłat). W tym przypadku opłata ta nawiązuje do profesjonalnego, a więc zarobkowego wykorzystywania dróg publicznych. Przyjęto zatem, że opłata za wydanie koncesji lub opłaty związane z transportem doraźnym powinny również powiększać pulę środków na wydatki publiczne związane z drogownictwem.

\section{Podsumowanie}

Analiza działalności legislacyjnej w Polsce w pierwszych latach po odzyskaniu niepodległości wskazuje, że problemy drogownictwa były obecne w polityce odradzającego się państwa. Dowodzi to, że kwestie gospodarcze (do których bez wątpienia zalicza się także budowę, utrzymanie i organizację zasad korzystania $\mathrm{z}$ dróg publicznych) stanowiły istotny element $\mathrm{w}$ drodze do odrodzenia demokratycznego państwa w kapitalistycznych realiach rynkowych. Budujące są również wnioski, że pomimo bardzo niskiego (w porównaniu do innych krajów) stopnia zmotoryzowania Polski i jej mieszkańców prawodawca tego okresu wychodził naprzeciw rewolucji motoryzacyjnej na świecie, przygotowując Polskę na jej przyjęcie, pod względem zarówno prawnym, jak i finansowym. Analizując najważniejsze regulacje prawne tego okresu, należy stwierdzić, że stanowiły one podwaliny współczesnych rozwiązań w zakresie dróg publicznych i zasad

\footnotetext{
48 Dz.Urz. Min.Kom. z 1935 r. Nr 23, poz. 180.
} 
korzystania z nich. Uwaga ta dotyczy zarówno miejsca administracji drogowej w ustroju administracyjnym państwa, jak i koncepcji finansowania tego zadania publicznego. Trzeba również podkreślić, że ówczesny prawodawca przyjął dojrzałe rozwiązania typowe dla państw demokratycznych, które można byłoby określić umownie jako systemowe. Były one wyraźnie oparte na założeniu, że drogownictwo stanowi zadanie publiczne, a więc generuje wydatki publiczne. $\mathrm{W}$ analizowanym okresie zadanie to (i odpowiednio wydatki na jego realizację) miało szczególne znaczenie z trzech powodów: po pierwsze - ze względu na stan dróg wynikający z destrukcyjnej polityki gospodarczej państw zaborczych, po drugie - ze względu na znaczenie ilości i jakości dróg publicznych dla odbudowy gospodarczej państwa, po trzecie - ze względu na zmianę jakościową i intensyfikację użytkowania dróg wynikającą z przypadającego na ten czas rozwoju motoryzacji. Wyraźnie dostrzegalne jest również założenie ówczesnego prawodawcy (typowe dla gospodarek kapitalistycznych), że użytkownicy dróg publicznych (z racji korzyści z tego dla nich wynikających) winni partycypować w wydatkach publicznych na ten cel. Wyrazem takiego założenia były daniny pobierane w związku z użytkowaniem dróg publicznych i ruchem drogowym. Podejście takie należy ocenić jako racjonalne i zgodne z powszechnym (i nadal aktualnym) wykorzystywaniem danin odpłatnych w polityce fiskalnej demokratycznego państwa opartego na gospodarce kapitalistycznej.

Ciężar partycypacji w wydatkach publicznych na cele związane $\mathrm{z}$ drogownictwem został rozłożony poprzez wykorzystanie różnych rodzajów daniny, pobieranych z różnych tytułów na podstawie kilku aktów prawnych. Można więc mówić o rozkładzie ciężaru fiskalnego poprzez obciążenie różnych form korzystania $\mathrm{z}$ dróg publicznych (a tym samym obciążenia różnych podmiotów) między innymi w związku z obciążeniem dróg publicznych sąsiadującą z nimi (przylegającą) infrastrukturą techniczną i lokowaniem reklam, czerpaniem korzyści gospodarczych wynikających z sąsiedztwa obiektów przemysłowych zlokalizowanych przy drogach, uczestnictwem w ruchu drogowym (legalizacja ruchu pojazdów mechanicznych, rejestracja pojazdów), w tym zwłaszcza z gospodarczego wykorzystywania dróg (koncesjonowanie działalności gospodarczej w branży transportowej). Ten (umownie nazywany systemem) zbiór danin publicznych oparty był na (powszechnym dla koncepcji danin odpłatnych) założeniu, że daniny te stanowią swoistą odpłatność jednostki (lub jej udział w wydatkach publicznych) za możliwość korzystania (zwłaszcza gospodarczego) z infrastruktury publicznej i czerpania z tego zindywidualizowanych i wymiernych korzyści gospodarczych. Wiele spośród przyjętych wówczas rozwiązań w różnej formie zachowało się również w dzisiejszym stanie prawnym i wpisuje się w system obciążeń publicznoprawnych transportu drogowego. 


\section{Bibliografia}

\section{Akty prawne}

Dekret z dnia 8 lutego 1919 roku w przedmiocie tymczasowych przepisów o zarządzie drogami kołowemi, Dz. Praw. P.Pol. z 1919 r. Nr 14, poz. 149.

Konwencja o sposobie opodatkowania obcokrajowych pojazdów mechanicznych podpisana w Genewie dnia 30 marca 1931 roku, Dz.U. R.P. z 1934 r. Nr 98, poz. 900 (ratyfikowana zgodnie z ustawą z dnia 5 marca 1934 roku, Dz.U. R.P. z 1934 r. Nr 27, poz. 218).

Okólniki z dnia 24 lipca 1933 roku w sprawie doraźnych przewozów osobowych pojazdami mechanicznymi poza obszarem jednej gminy, Dz.Urz. Min.Kom. z 1935 Nr 23, poz. 180.

Okólnik Nr 33 z dnia 11 maja 1936 roku w sprawie opłat specjalnych i dopłat drogowych (Nr SF. 665-2), Dz.Urz. Min.Kom. z 1937 r. Nr 52, poz. 4567.

Rozporządzenie Ministra Robót Publicznych z dnia 9 maja 1919 roku w przedmiocie regulaminu Komitetu drogowego przy Ministerstwie Robót Publicznych, Dz.Praw. P.Pol. z 1919 r. Nr. 39, poz. 286.

Rozporządzenie Rady Ministrów z dnia 20 maja 1920 roku w przedmiocie stosunku służbowego inżynierów drogowych, Dz.U. z 1920 r. Nr. 47, poz. 289.

Rozporządzenie Ministra Komunikacji wydane w porozumieniu z Ministrami: Spraw Wewnętrznych, Spraw Wojskowych, Przemysłu i Handlu, Sprawiedliwości, Poczt i Telegrafów oraz Skarbu, a co do $\S 5 \mathrm{w}$ porozumieniu z Ministrem Spraw Wewnętrznych z dnia 6 lipca 1932 roku w sprawie wykonania ustawy o zarobkowym przewozie osób i towarów pojazdami mechanicznymi, Dz.U. R.P. z 1932 r. Nr 95, poz. 821.

Rozporządzenie Rady Ministrów z dnia 12 lipca 1934 roku o zwolnieniu od opłat niektórych pojazdów mechanicznych, Dz.U. R. P. z 1934 r. Nr 69, poz. 636.

Rozporządzenie Ministra Skarby z dnia 18 lipca 1935 roku o odprawie celnej środków przewozowych, Dz.U. R.P. z 1935 r. Nr 60, poz. 387.

Rozporządzenie Ministrów Komunikacji, Spraw Wewnętrznych i Spraw Wojskowych z dnia 27 października 1937 roku wydane w porozumieniu z Ministrem Opieki Społecznej o ruchu pojazdów mechanicznych na drogach publicznych, Dz.U. R.P. z 1937 r. Nr 85, poz. 616.

Rozporządzenie Ministrów Komunikacji i Spraw Wewnętrznych z dnia 1 października 1962 roku w sprawie ruchu na drogach publicznych, Dz.U. z 1962 r. Nr 61, poz. 295.

Rozporządzenie Ministrów Komunikacji i Spraw Wewnętrznych z dnia 20 lipca 1968 roku w sprawie ruchu na drogach publicznych, Dz.U. z 1968 r. Nr 27, poz.183.

Ustawa z dnia 10 grudnia 1920 roku o budowie i utrzymaniu dróg publicznych w Rzeczypospolitej Polskiej, Dz.U. R.P. z 1921 r. Nr 6, poz. 32.

Ustawa z dnia 7 października 1921 roku o przepisach porządkowych na drogach publicznych, Dz.U. R.P. z 1921 r. Nr 89, poz. 656 ze zm.

Ustawa z dnia 3 lutego 1931 roku o Państwowym Funduszu Drogowym, Dz.U. R.P. z 1933 r. Nr 45, poz. 352.

Ustawy z dnia 22 marca 1933 roku o zarobkowym przewozie osób pojazdami mechanicznymi w obrębie gminy miejskiej, Dz.U. R.P. z 1933 r. Nr 32, poz. 273.

Ustawa z dnia 8 stycznia 1951 roku o transporcie drogowym, Dz.U. z 1951 r. Nr 4, poz. 26.

Ustawa z dnia 27 listopada 1961 roku o transporcie drogowym i spedycji krajowej, Dz.U. z $1961 \mathrm{r}$. $\mathrm{Nr} 53$, poz. 297.

Ustawa z dnia 29 marca 1962 roku o drogach publicznych, Dz.U z 1962 r. Nr 20, poz. 90.

Ustawa z dnia 1 lutego 1983 roku Prawo o ruchu drogowym, Dz.U. z 1992 r. Nr. 11, poz. 41.

Ustawa z dnia 21 marca 1985 roku o drogach publicznych, Dz.U. z 2018 r. poz. 2068 tekst jedn.

Studia nad Autorytaryzmem i Totalitaryzmem 41, nr 4, 2019

(C) for this edition by CNS 
Ustawa z dnia 20 czerwca 1997 roku Prawo o ruchu drogowym, Dz.U. z 2018 r. poz. 1990 tekst jedn.

Ustawa z dnia 29 sierpnia 1997 roku o warunkach wykonywania krajowego drogowego przewozu osób, Dz.U. z 1997 r. Nr 141, poz. 942.

Ustawa z dnia 6 września 2001 roku o transporcie drogowym, Dz.U. z 2019 r. poz. 58 tekst jedn.

\section{Literatura}

Adam L., Podatki i opłaty w kapitalizmie, Warszawa 1962.

Antonów D., Cechy danin publicznych w polskim systemie prawa, „Annales Universitatis Mariae Curie-Skłodowska. Sectio G. Ius" 2016, nr 1.

Antonów D., Opłata skarbowa w polskim porządku prawnym, Warszawa 2017.

Antonów D., Opłaty publiczne na gruncie ustawy o publicznym transporcie zbiorowym - wybrane problemy, [w:] Finanse samorzadowe po 25 latach samorzadności. Diagnoza i perspektywy, red. W. Miemiec, Warszawa 2015.

Antonów D., Opłaty publiczne w działalności gospodarczej na przykładzie branży transportu drogowego, „Annales Universitatis Mariae Curie-Skłodowska. Sectio H. Oeconomia” 50, 2016, nr 1.

Antonów D., Szczególne opłaty administracyjne, Wrocław 2017.

Antonów D., Unifikacja opłat stemplowych w okresie rzadów sanacji-ustawa z dnia 1 lipca 1926 roku o opłatach stemplowych, ,Studia nad Autorytaryzmem i Totalitaryzmem” 40, nr 4.

Collier J.L., The Automobile, New York 2006.

Czaja-Hliniak I., Optaty i dopłaty w Polsce międzywojennej, Kraków 2013.

Czubiński A., Znaczenie odbudowy niepodległego państwa dla narodu polskiego, „Roczniki Historyczne" $36,1970$.

Dell R.M., Moseley P.T., Rand D.A.J., Towards Sustainable Road Transport, Oxford 2014.

Horszowski J., Daniny komunalne na utrzymanie i budowę komunalnych dróg publicznych, „Ruch Prawniczy, Ekonomiczny i Socjologiczny" 1924, nr 2.

Mairanc A., Kodeks Automobilowy. Ustawy. Rozporządzenia. Okólniki. Orzecznictwo. Komentarz, Warszawa 1938.

Nestorowicz M.W., Sprawa drogowa w Polsce, Warszawa 1923.

Ptak M., Regionalne $i$ lokalne opłaty $i$ podatki transportowe jako instrumenty przeciwdziałania zmianom klimatu, „Studia Ekonomiczne. Uniwersytet Ekonomiczny w Katowicach” 2013, nr 143. Wspótczesne uwarunkowania rozwoju transportu w regionie.

Romanow P., Koszt transportu $w$ działalności przedsiębiorstw transportu drogowego, „Logistyka” 2013, nr 2 .

Szymonik A., Gałuszczak W., Koszty transportu i ceny ustug transportu samochodowego, „Logistyka" 2013, nr 2.

Wójcik T., Centralne Warsztaty Samochodowe w Warszawie w latach 1918-1928: przyczynek do genezy polskiej motoryzacji, „Przegląd Historyczno-Wojskowy” 14 (65)/2 (244).

\section{PUBLIC LEVIES CONNECTED WITH THE USE OF PUBLIC ROADS AND THE ROAD TRAFFIC IN THE DEMOCRATIC SYSTEM OF REBORN POLAND}

\section{Summary}

The article is devoted to public levies connected with the use of public roads and the road traffic in the democratic system of reborn Poland (i.e. after regaining independence). Problems con- 
nected with public roads (first of all financing of building and maintaining the roads) as the elements of politics of democratic Poland in range of its economic restoration in the capitalist economic system after many years of annexation are described in the article. During that period the state collected different charges and other levies from participants of the road traffic and other subjects using public roads in different ways (e.g. industrial companies located by the roads, which use the roads in other way than normal users, that means they often transport heavy things by big vehicles). Takings from the levies were allocated for building and maintenance of public roads. The most important kinds of levies are shown and discussed in the article. An assessment of the politics of Poland in the field of road infrastructure during the first years after regaining independence is also conducted in the article.

Keywords: annexation, democratic system, capitalism, administrative system, road managing, public tasks in democratic system, levies in capitalism, public levies, charges, taxes, public roads, road traffic, regaining independence, motorization, mechanical vehicle, public expenditures.

Dobrosława Antonów

dobroslawa.antonow@uwr.edu.pl 